\title{
The Effect of Trust and Service Quality to Customer Value Moderated by the Perceived Ease of Use (Case Study Bluebird Taxi in Indonesia)
}

\author{
M. Ali Iqbal \\ Senior Lecturer at Mercubuana University, Jakarta, Indonesia \\ Rhian Indra Dewa \\ Senior Lecturer at Esa Unggul University, Jakarta, Indonesia \\ Yanti Murni \\ Senior Lecturer at Mercubuana University, Jakarta, Indonesia \\ Dharma Putra \\ Senior Lecturer at Mercubuana University, Jakarta, Indonesia
}

\begin{abstract}
Taxi is one of the means of land transportation growing and developing quite rapidly since the 90s has become one of the prima donas of alternative transportation in Indonesia. PT. Blue Bird Pusaka is a business entity that concentrates one of its business sectors in the transportation services industry sector, namely taxis. The rapid development of the business world today causes companies to face intense competition. Competition is not only between conventional taxi companies but also with online taxis. Blue Bird's revenue in 2015 still recorded a pretty good revenue growth performance. However, once entering 2016, Blue Bird's income continues to decline every quarter. In the first quarter of 2016, Blue Bird's revenue was valued at Rp1.27 trillion, down 11 percent from the fourth quarter of 2015 amounting to Rp1.43 trillion. In the following quarter, Blue Bird's revenue reached Rp1.19 trillion, down 6 percent from the first quarter of 2016. In the third quarter, the company's revenue dropped again to Rp1.17 trillion. In the fourth quarter, the company earned revenues of Rp1.15 trillion, down 2 percent from the previous quarter. In early 2017, the downward trend in Blue Bird's income continued. In the first quarter of 2017 , the company's revenue dropped 10 percent by posting revenues of Rp1.03 trillion. This achievement has also been the lowest point since 2015. This study aims to examine the phenomenon of customer value, seen from the trust and quality of service and perceived ease of use as a moderating variable. This type of research is a conclusive design research that is the type of inference research that aims to test a particular hypothesis, either through indepth research on a problem (descriptive) or looking for relationships between variables (correlative) between the independent variable and the dependent variable. The analytical method uses testing with Moderated Regression Analysis (MRA) with its analysis tool SPSS 22. The outcome of this study shows that trust has a positive effect on customer value and service quality has a positive effect on customer value. Perceive ease of use as moderating variable between trust and service quality to customer value both of them are negatively and significantly. This condition occurs because most respondents aged 35 years and over where the category of respondents are not too familiar with technology and the use of technology for them is not something that makes it easy to interact.
\end{abstract}

Keywords: trust, service quality, perceived ease of use, customer value

DOI: $10.7176 / \mathrm{EJBM} / 12-18-09$

Publication date:June 30th 2020

\section{Introduction}

\subsection{Research Background}

Transportation can be interpreted as an activity to move a (person or item) from one place to another separately. The existence of transportation is nothing but as a support for daily human activities, and is a means of human mobility on land, sea and air. Certain control and control systems (traffic management, operating systems, and equipment procedures. One of the means of land transportation is taxis, taxis are one of the means of land transportation growing and developing quite rapidly since the 90 s has become one of one prima donna alternative transportation in Indonesia.taxis have the ability to reach all urban / urban areas.

One of the conventional taxis in Indonesia and known by the public is the bluebird taxi. PT. Bluebird Pusaka is a business entity that concentrates one of its business sectors in the transportation services industry sector, namely taxis. As a private company, of course, PT. Bluebird Pusaka is here to benefit and provide satisfying services for consumers. But not only PT. Bluebird Pusaka itself is engaged in the field of taxi transportation services so that this creates competition between companies engaged in this field.

The rapid development of the business world today causes companies to face intense competition. 
Competition is not only between conventional taxi companies but also with online taxis. The company generally wants its customers to be maintained forever. To realize this, it is not something that is easily climatic, as business competition is very tight at the moment considering that there are rapid changes that can occur at any time such as changes in customers, competitors or changes in broad conditions that are always dynamic.

Bluebird's revenue in 2015 still recorded a pretty good revenue growth performance. However, once entering 2016, bluebird's income continues to decline every quarter. In the first quarter of 2016, bluebird's revenue was valued at Rp1.27 trillion, down 11 percent from the fourth quarter of 2015 amounting to Rp1.43 trillion. In the following quarter, bluebird's revenue reached Rp1.19 trillion, down 6 percent from the first quarter of 2016. In the third quarter, the company's revenue dropped again to Rp1.17 trillion. In the fourth quarter, the company earned revenues of Rp1.15 trillion, down 2 percent from the previous quarter. In early 2017, the downward trend in bluebird's income continued. In the first quarter of 2017, the company's revenue dropped 10 percent by posting revenues of Rp1.03 trillion. This achievement has also been the lowest point since 2015.

\subsection{Research objective and questions}

The objective of this research is expected to be able to examine the phenomenon of customer value, seen from the quality of service, trust and perceived ease of use. Based on the explanation set forth above, the research questions can be defined and formulated as follows:

1. Does trust affect customer value?

2. Does the quality of service affect customer value?

3. Does trust affect customer value with perceived ease of use as a moderating variable?

4. Does service quality affect customers value with perceived ease of use as a moderating variable?

\section{Theoretical Framework and Hypothesis}

\subsection{Trust}

According to Kotler and Pfoertsch (2007) trust is a descriptive idea held by someone about something ". Trust is a key element of relationship success and the linking trend towards various services and satisfaction ratings felt by Arisutha's customers (2005). Elrado, (2014: 48) trust is the willingness of individuals to depend on others involved in exchange because the individual has confidence to the other party Trust will occur if someone has confidence in an exchange with a partner who has integrity and can be trusted, Morgan and Hunt (2004: 16). Donney and Conno (1997: 7), explain in detail the factors that influence it such as the company's reputation, the size of the company, and whether the company can provide a sense of security for consumers. Dormas et.al (2014) stated that statistically positive values to the relationship of trust were found in the line staff ahead of the company's perceived value, but Laura N (2016) stated that the trust negatively effects and significant with the customer's value.

\subsection{Service quality}

According to Kotler (2007), quality is defined as the characteristics and overall nature of goods and services that affect the ability to meet the stated or implied needs of consumers. Pawirosumarto and Liestijati (2017) in their study stated that product, price, and quality directly affect customer satisfaction. Kotler and Keller (2009) also reinforce this statement, namely the existence of services in accordance with consumer expectations, will lead to customer satisfaction. Andreassen and Lidested (1997: 21) states that service quality has an influence on consumer value. Wang and Hing-Po (2004) found that customer perceived service quality is positif relationship to customer value. Lupiyoadi and Hamdani (2006) state that one way to create customer satisfaction is to improve service quality, because consumers are the main focus when talking about customer satisfaction. It is said that, the consistency of product and service quality can contribute to the company's success in terms of customer satisfaction. Many previous studies have shown that service quality has a significant influence on customer satisfaction (Lee, 2013).

\subsection{Customer Value}

Kotler (2007) argues that customer value is the difference between total customer value and total customer cost. Wang et.al. (2004) found the role of customer value on customer satisfaction, brand loyalty and customer behavior based on CRM performance. Kotler (2007) states that brand loyalty is one of brand assets, which shows the high value of loyalty, because to build it there are many challenges that must be faced and require a very long time. Ho et.al (2014) said that companies must be able to create customer value in the process of buying and providing good service. Therefore, companies must be able to utilize people's preferences, create services, and market surveys in order to be able to support customer value for the products they produce better and satisfactorily Lunt and Percivil (2010). 


\subsection{Perceived Ease of Use}

The concept of perceived ease of use shows the degree to which a person believes that the use of a new technology is easy and does not require the user's effort to use it (Santoso, 2010). Perceived ease of use according to Wijana (2010) means individual belief that using information technology systems will not be inconvenient or require huge effort when used. Davis et.al (1989) defines that perception of ease as a level where a person believes that the use of something will reduce one's efforts. These results support the findings of Farizi (2013) that a person's belief that an information system is easy to use, then that person will decide to use or not use the technology. Chuchuen (2016) states that perceptions of ease of use in the mobile banking system its customers gain profits and are accustomed to in mobile banking or electronic banking applications have a high interest in using mobile banking. Zhang et.al (2015) shows the results of his research that the perceived ease of use has a positive and significant effect on consumer spending interests on new products. The results of Cho and Esen's research (2015) showed a significant influence from perceived usefulness to online shopping interest. Chiu and Wang (2008) state that perceived ease of use is positively related to ongoing interest in the context of Web-Based learning.

Empirical studies conducted by Chau and Lai (2003) show that perceptions of ease are positively related and have a significant effect on the use of internet banking, Ramadhani Research (2008) has explained that the ease of using internet banking that has been provided by banks is easy to understand and easy to use so will reduce the customer's effort to learn how to transact using internet banking. Individual perception related to the ease of using a computer (perceived ease of use) is the level where individuals believe that using a particular system will be free from errors. This perception will then have an impact on behavior, i.e. the higher one's perception of the ease of using the system, the higher the level of information technology utilization (Igbaria et.al, 2000) on the other hand the tendency of an individual to be uneasy, apprehensive, stressed or have anxious feelings about the use of selfservice banking technologies (SSBTs), is a similar construct to computer anxiety, a variable that has been found to have a negative effect on perceived ease of use (Venkatesh, 2000). Rose J and Gerard F (2006) found that adult age is negatively related to internet self-efficacy because old age has difficulty in running internet applications because they feel they do not have full confidence in using the application. Murni Y (2019) found in her reseach that consumer confidence to shop online is still low.

Development of Hypotheses and Thinking Frameworks

Based on a review of the theory that has been raised previously, the research hypothesis is proposed as follows:

H1: Trust affects customer value

H2: Service quality affects customer value

H3: Trust, which are moderated by perceived easy of use affects customer value

H4: Service quality, which are moderated by perceived easy of use affects customer value

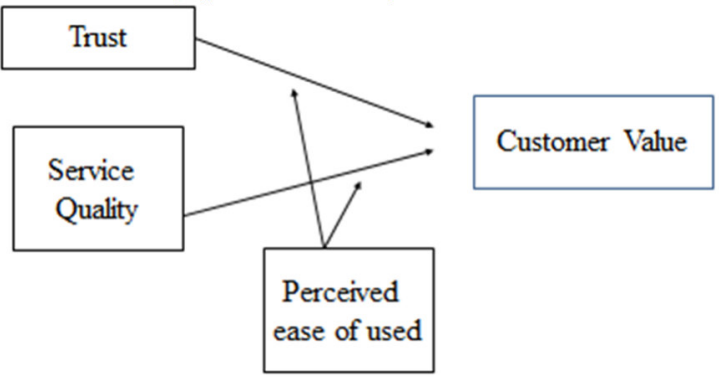

Figure 2. Research Model

\section{Methodology}

To answer the research questions, quantitative approaches are adopted. Quantitative research aims to test the research model, the significance of the relationships among the variables and factors, and the hypotheses (Saunders and Lewis, 2012). This stage consists of four activities: a pre-test survey, establishment of the research model, a confirmatory study, and data analysis (Neuman, 2006). In the quantitative approach, researchers commonly implement a non probability sampling technique. The population for this survey consists of all Indonesian people who use blue bird taxi transportation service. A quantitative method was used, which involved administering a questionnaire to selected respondents who included Indonesian people who use blue bird taxi transportation service. Survey was conducted by distributing questionnaires containing preliminary closed-ended questions used a six-point Likert scale to 64 Indonesian people who use blue bird taxi transportation service. Data analysis using testing with Moderated Regression Analysis (MRA).

\section{Research Results and Research Discussion 4.1 Validity and Reliability Test}

Based on the results of data processing in the Table below, all indicators show validity which is above 0.361 ( 30 
samples). The reliability of the measurement model is tested by examining the value of Cronbach's alpha. Cronbach's alpha measures the lower limit value of the reliability of a construct. Constructs are reliable if the Cronbach's alpha values are greater than 0.70 , while the composite reliability must be greater than 0.70 . Cronbach's alpha is higher than 0.7 are considered satisfactory (Hair et al., 2011). Croanbach alpha value in this study is above 70 i.e. customer trust (0.854), service quality (0.896), perceived ease of use $(0.869)$ and customer value $(0.861)$

Tabel. 4.1. Test the validity and Reliability of Trust, Service Quality, Perception of Ease of Use and Customer Value

\begin{tabular}{|c|c|c|c|}
\hline Variable & Indicators & \multicolumn{2}{|l|}{ Validity } \\
\hline \multirow[t]{3}{*}{ Consumer trust } & Honesty & .908 & .854 \\
\hline & Benevolence & .907 & \\
\hline & competence & .823 & \\
\hline \multirow[t]{5}{*}{ Service quality } & Tangible & .843 & .896 \\
\hline & Reliability & .857 & \\
\hline & Responsiveness & .887 & \\
\hline & Assurance & .824 & \\
\hline & Empathy & .811 & \\
\hline \multirow{4}{*}{$\begin{array}{l}\text { Perceived easy of } \\
\text { used }\end{array}$} & Clear and understable & .910 & .869 \\
\hline & does not requaire alot of mental effort & .772 & \\
\hline & easy to use & .872 & \\
\hline & (easy to get the system to do what he/she wants to do & .834 & \\
\hline \multirow[t]{4}{*}{ Consumer value } & Emotion Value & 0.765 & .861 \\
\hline & Social Value & 0.761 & \\
\hline & Quality Value & 0.938 & \\
\hline & Price Value & 0.900 & \\
\hline
\end{tabular}

Source: Processing Results SPSS

\subsection{Classic assumption test}

4.2.1. Normality test

Tabel. 4.2. Test Normality for Trust, Service Quality, Perceived Ease of Use and Customer Value

One-Sample Kolmogorov-Smirnov Test

\begin{tabular}{|ll|r|r|r|r|}
\hline & & $X 1$ & $X$ & X3 & $Y$ \\
\hline N & & 64 & 64 & 64 & 64 \\
& Mean & 13.75 & 23.34 & 17.02 & 17.61 \\
Most Extreme Differences & Std. Deviation & 2.449 & 3.965 & 3.610 & 3.135 \\
& Absolute & .106 & .102 & .099 & .132 \\
& Positive & .106 & .081 & .080 & .098 \\
Kolmogorov-Smirnov Z & Negative & -.103 & -.102 & -.099 & -.132 \\
Asymp. Sig. (2-tailed) & & .850 & .814 & .795 & 1.056 \\
& & .465 & .522 & .552 & .215 \\
\hline
\end{tabular}

a. Test distribution is Normal.

b. Calculated from data.

Source: Processing Results SPSS

The results of the analysis show the four variables are normally distributed, this is because the KS $\mathrm{Z}$ value for the four variables is above 0.05 , each of which is trust (.850), service quality (.814), perceived ease of use (.795) and customer value (1.056) 


\subsubsection{Heteroscedasticity Test}

\section{Scatterplot}

\section{Dependent Variable: $Y$}

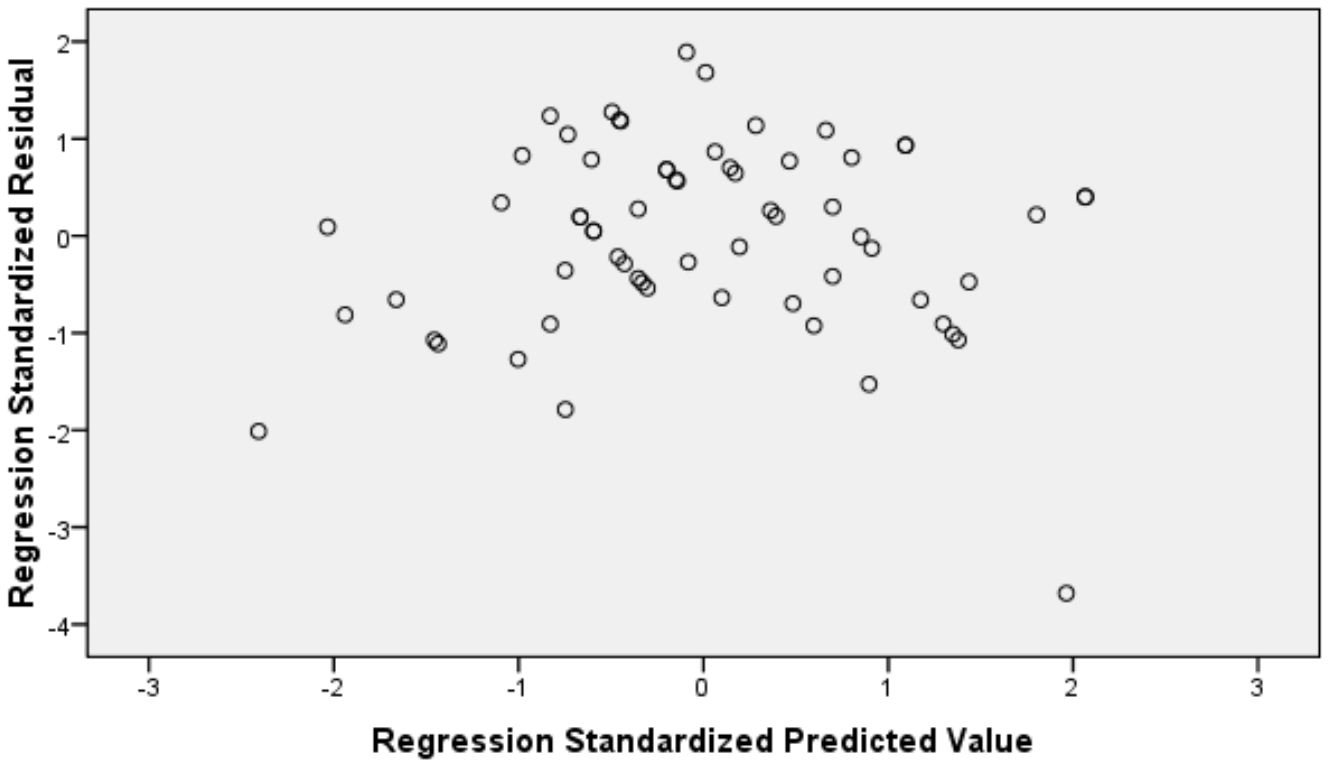

Source: Processing Results SPSS

Figure 4.1 Heteroscedasticity Test Results

From Figure above it can be seen that the dots randomly spread, and it can be concluded that there is no heteroscedasticity in the regression model. It can be concluded that the regression model is eligible to predict customer value

\subsection{Regression analysis}

Table 4.3. Simple Regression Analysis of Trust in Customer Value

\section{Coefficients ${ }^{\mathrm{a}}$}

\begin{tabular}{|l|r|r|r|r|r|}
\hline \multirow{2}{*}{ Model } & \multicolumn{2}{|c|}{ Unstandardized Coefficients } & Standardized Coefficients & & \\
\cline { 2 - 6 } & \multicolumn{1}{|c|}{ B } & Std. Error & Beta & \multicolumn{1}{c|}{ Sig. } \\
\hline 1 (Constant) & 3.250 & 1.312 & & 2.477 & .016 \\
X1 & 1.044 & .094 & .816 & 11.112 & .000 \\
\hline
\end{tabular}

a. Dependent Variable: Y

Source: Processing Results SPSS

In table 4.3 it can be seen that the value of trust sig $(\mathrm{X} 1)$ is 0.000 where the value is smaller than $\alpha=0.05$ so $\mathrm{H} 0$ is rejected and $\mathrm{H} 1$ is accepted. That means trust has a positive effect on customer value.

Table 4.4. Simple Regression Analysis of Service Quality on Customer Value

\section{Coefficients ${ }^{\mathrm{a}}$}

\begin{tabular}{|c|c|c|c|c|c|}
\hline \multirow[b]{2}{*}{ Model } & \multicolumn{2}{|c|}{ Unstandardized Coefficients } & \multirow{2}{*}{$\frac{\text { Standardized Coefficients }}{\text { Beta }}$} & \multirow[b]{2}{*}{$\mathrm{t}$} & \multirow[b]{2}{*}{ Sig. } \\
\hline & B & Std. Error & & & \\
\hline 1 (Constant) & 2.818 & 1.422 & & 1.981 & .052 \\
\hline $\mathrm{X} 2$ & .634 & .060 & .8 & 10.549 & .000 \\
\hline
\end{tabular}

a. Dependent Variable: Y

Source: Processing Results SPSS

In table 4.4 it can be seen that the value of service quality $\operatorname{sig}(\mathrm{X} 2)$ is 0.000 where the value is smaller than $\alpha$ $=0.05$ so that $\mathrm{H} 0$ is rejected and $\mathrm{H} 1$ is accepted. This means that service quality has a positive effect on customer value 


\subsection{Moderated Regression Analysis Model}

The results of Moderated Regression Analysis seen in Table 4.5 and Table 4.6 as follows:

Table. 4.5. Result of Testing Moderate Regression Analysis Hipotesis 3

\section{Coefficients}

\begin{tabular}{|l|r|r|r|r|r|}
\hline \multirow{2}{*}{ Model } & \multicolumn{2}{|c|}{ Unstandardized Coefficients } & Standardized Coefficients & \\
\cline { 2 - 6 } & \multicolumn{1}{|c|}{ B } & Std. Error & Beta & \multicolumn{1}{c|}{ Sig. } \\
\hline 1 (Constant) & -10.073 & 3.997 & -2.520 & .014 \\
X1 & 1.552 & .291 & 1.212 & 5.325 & .000 \\
X3 & 1.058 & .243 & 1.218 & 4.350 & .000 \\
Moderate1 & -.049 & .017 & -1.279 & -2.925 & .005 \\
\hline
\end{tabular}

a. Dependent Variable: Y

Source: Processing Results SPSS

Table. 4.6. Result of Testing Moderate Regression Analysis Hipotesis 4

\section{Coefficients $^{\mathrm{a}}$}

\begin{tabular}{|l|r|r|r|r|r|}
\hline \multirow{2}{*}{ Model } & \multicolumn{2}{|c|}{ Unstandardized Coefficients } & Standardized Coefficients & \\
\cline { 2 - 6 } & \multicolumn{1}{|c|}{$\mathrm{B}$} & Std. Error & Beta & $\mathrm{t}$ & Sig. \\
\hline 1 (Constant) & -14.314 & 3.962 & & -3.613 & .001 \\
$\mathrm{X} 2$ & 1.079 & .172 & 1.364 & 6.285 & .000 \\
$\mathrm{X} 3$ & 1.265 & .232 & 1.457 & 5.452 & .000 \\
Moderate2 & -.037 & .010 & -1.570 & -3.820 & .000 \\
\hline
\end{tabular}

a. Dependent Variable: Y

Source: Processing Results SPSS

Based on Table 4.5 and 4.6 a simple linear regression equation model can be made, as follows:

$\mathrm{Y}=-10.073+1.552 \mathrm{X} 1+1.058 \mathrm{X} 3-0.049(\mathrm{X} 1)(\mathrm{X} 3)$

$\mathrm{Y}=-14.314+1.079 \mathrm{X} 2+1.265 \mathrm{X} 3-0.037(\mathrm{X} 2)(\mathrm{X} 3)$

Table 4.5 and Table 4.6 show the interaction of moderating variables perceived ease of use (X3) has a negative coefficient that is -.049 and -.037 with a significance level of 0.005 and 0.000 less than $\alpha=0.05$. This means that perceived ease of use moderate the relationship between trust in customer value and service quality to customer value negatively and significantly.

\section{Finding and Discussion}

Hypothesis 1 shows that trust has a positive effect on customer value, meaning that if customer trust increases, customer value will also increase. To increase customer value for bluebird transportation services, it is important to consider customer trust in these services such as honesty, virtue and competence of blue bird transportation service drivers.

Hypothesis 2 shows that service quality has a positive effect on customer value, meaning that if service quality increases, customer value will also increase. To increase customer value for bluebird transportation services, it is also necessary to pay attention to the quality of services such as ride comfort, driver courtesy, safety in the vehicle and driver empathy for the service users.

Hypothesis 3 and hypothesis 4 show the interaction of moderating variables perceived ease of use has a negative coefficient of -.049 and -.037 with a significance level of 0.005 and 0.000 less than $\alpha=0.05$. This means that perceived ease of use moderate the relationship between trust in customer value and service quality to customer value negatively and significantly. This condition occurs because most respondents aged 35 years and over where the category of respondents are not too familiar with technology and the use of technology for them is not something that makes it easy to interact.

\section{Conclution}

\subsection{Practical implications}

Trust and service quality have a significant effect on customer value. For that reason, in order to increase customer value, it is necessary to consider policies to maintain trust such as honesty, virtue and competence of blue bird transportation service drivers and quality of service such as ride comfort, driver courtesy, safety in the vehicle and driver empathy for the service user 


\subsection{Theoretical contributions}

Trust has a positive effect on customer value, this is in line with research Dormas et al (2014) which states that trust is positively related to perceived value. Service quality has a positive effect on customer value, this is in line with research Andreassen and Lidested (1997: 21) which states that service quality has an influence on consumer value.

Perceived ease of use moderates the relationship between trust in customer value and service quality to customer value negatively and significantly. This condition occurs because most of the adult respondents $(>35$ years) in which the category of respondents are not too good at technology and the use of technology for them is not something that makes it easy to interact. This is in line with research by Rose J and Gerard F (2006) who found that adult age is negatively related to internet self-efficacy because old age has difficulty in running internet applications because they feel they do not have full confidence in using the application. Venkatesh (2000) found that the tendency of an individual to be uneasy, apprehensive, stressed or have anxious feelings about the use of self-service banking technologies (SSBTs), is a similar construct to computer anxiety, a variable that has been found to have a negative effect on perceived ease of use. Murni Y (2019) said that consumer confidence to shop online is still low.

\subsection{Limitations of research}

This study only examines variables of service quality, trust and perceived ease of customer value and does not explore other variables that affect customer value. This study only focuses on bluebird taxis so that the results of this study cannot be generalized for other taxi transportation services.

\subsection{Future research direction}

Further research needs to be developed for more other taxi transportation services so that the results can be generalized to each taxi transportation service. Further research can also explore other independent variables that have not been examined in this study such as customer satisfaction, brand and other variables that affect customer value.

\section{References}

Andreassen, Wallin \& Lindestad. 1997. The Impact of Corporate Image on Quality, Customer Satisfaction, and Loyalty for Customer with Varying Degrees of Service Expertise. The International Journal of Service Industry Management, 8 (4): 14-15.

Arisutha, D. (2005). Dimensions of Service Quality. Jakarta: Gramedia Pustaka Publishers Barnes, Stuart and Vidgen Richard.2001. an Integrative Approach to The Assessment of E-Commerce Quality. Journal of Electronic Commerce Research. 3 (3).

Chau, P.Y.K. and Lai, V.S.K. 2003. An empirical investigation of the determinants of user acceptance of internet banking. Journal of Organizational Computing \& Electronic Commerce. Vol. 13 No. 2, pp. 123-45.

Chiu, C.-M., Wang, E. T. G. 2008. Understanding Web-based learning continuance intention: The role of subjective task value. Information \& Management, 45(3), 194-201.

Cho Yoon C and Esen Sagynov (2015). Exploring Factors That Affect Usefulness, Ease Of Use, Trust, And Purchase IntentionIn The Online Environment. International Journal of Management \& Information Systems - First Quarter 2015 Volume 19, Number 1

Chuchuen Chat (2016). The Perception of Mobile Banking Adoption: The Study of Behavioral, Security, and Trust in Thailand. International Journal of Social Science and Humanity, Vol. 6, No. 7, July 2016: 547-540

Davis, F.D, R.P. Bagozzi, dan PR. Washaw. 1989. User Acceptance of Computer Technology: A Comparison of Two Theoritical Models, International Journal Management Machine Studies, August, Vol. 35, No. 8, pp. 982- 1003

Dormas K.B.H, Jose Marcos Carvalho de Mesquita and Rachel Patrocinio1 (2014). The Relationship between Trust, Value and Loyalty in the Internet Era. Journal of Business and Economics, ISSN 2155-7950, USA June 2014, Volume 5, No. 6, pp. 802-812

Doney, P.M. and Cannon, J. P. (1997), "An Examination of the Nature of Trust in Buyer-Seller Relationship," Journal of Marketing, Vol. 61, pp. 35-51

Elrado MH. (2014), Pengaruh Kualitas Pelayanan Terhadap Kepuasan, Kepercayaan dan Loyalitas Survei pada Pelanggan yang Menginap di Jambuluwuk Batu Resort Kota Batu, Jurnal Administrasi Bisnis (JAB), Vol.15 No.2

Farizi, Hadyan. 2013. Pengaruh Persepsi Kegunaan, Persepsi Kemudahan, Persepsi Risiko dan Kepercayaan Terhadap Minat Menggunakan Internet Banking, Jurnal Keuangan dan Perbankan, Vol. 2, No. 2.

Hair, J.F., Ringle, C.M. and Sarstedt, M. (2011) 'PLS-SEM: indeed a silver bullet', Journal of Marketing Theory and Practice, Vol. 19, No. 1, pp.139-151.

Ho,Y.C., M.J. Hsieh, and A.P. Yu, "Effects of Customer-value Perception and Anticipation on Relationship 
Quality and Customer Loyalty in Medical Tourism Services Industry," Information Technology Journal, vol. 13, no. 4, pp. 652-660, 2014.

Igbaria, M., Anandarajan, M., dan Anakwe, U. 2000. "Technology Acceptance in The Banking Industry: A Perspective from A Less Developed Country," Information Technology and People, MCB University Press, pp. 298-312.

Kotler, P., \& Pfoertsch, W. (2007). B2B brand management. The Marketing Review, 7 (2), 201- 203.

Kottler, Philp and K. Lane Keller. 2009. Marketing Management. New Jersey Publisher Prentice Hall Laura Netty (2016). The Effect of Trust and Service Quality Toward Patient Satisfaction with Customer Value as Intervening Variable Binus Business Review, 7(2), August 2016, 157-162.

Laura Netty (2016). The Effect of Trust and Service Quality Toward Patient Satisfaction with Customer Value as Intervening Variable Binus Business Review, 7(2), August 2016, 157-162.

Lee, H. S. (2013). Major moderators influencing the relationships of service quality, customer satisfaction and customer loyalty. Asian Social Science, 9(2), 1-11

Lupiyandi Rambat and Hamdi A. 2006. Service Marketing Management, Jakarta: Salemba Empat

Morgan, R.M. and Hunt, S.D. (1994), "The commitment-trust theory of relationship marketing", Journal of Marketing, Vol. 58 No. 3, pp. 20-38.

Murni Y (2018). Analysis of the Influence of Trust, Easiness in Shopping, Product Quality to Customer Satisfaction to Increaseness in Shopping Customer Loyalty Online Shopping. International Journal of Economics, Business and Management Research, Vol.2, No. 04, p. 61

Neil Lunt and Percivil Carrera, "Medical Tourism: Assessing the Evidence on Treatment Abroad," Journal Maturitas, vol. 66, no. 1, pp. 27-32, February 2010.

Neuman, W.L. (2006) Social Research Methods: Qualitative and Quantitative Approaches, 6th ed., Pearson Education Inc., New York.

Pawirosumarto. And Liestijati. 2017. The Effect of Products, Price, And Service Quality on Customer Satisfactionin "Rice for the Poors" Program. RJOS, 12 No 72, December 2017.

Ramadhani, R. 2008. Analisis Faktor Faktor yang Mempengaruhi Penerimaan Nasabah Terhadap Layanan Internet Banking di Semarang : Dengan Menggunakan Pendekatan TAM. Skripsi. Universitas Islam Indonesia.

Rose J and Gerard Fogarty. 2006. Determinats of Perceived usefulness and Perceived Ease of Use in the Technology Acceptance Model: Seniors Consumers Adoption of Self Service Banking Technologes. Academy of World Business, Marketing \& Management DevelopmentConference Proceedings. Volume 2 No 10, July 2006

Santoso, Budi. 2010. Pengaruh Perceived Usefulness, Perceived Ease of Use, dan Perceived Enjoyment Terhadap Penerimaan Teknologi Informasi: Studi Empiris di Kabupaten Sragen. Tesis Fakultas Ekonomi Universitas Sebelas Maret.

Saunders, M. and Lewis, P. (2012) Doing Research in Business Management: an Essential Guide to Planning Your Project, Prentice Hall, USA

Venkatesh, V., \& Davis, F. D. (2000). A theoretical extension of the technology acceptance model: Four longitudinal field studies. Management Science, 46(2), 186-204.

Wang, Yonggui., Hing, P. L., Chi R., and Yang, Y (2004). An Integrated Framework for Customer Value And Customer Relationship Management Performance: A Customer Based Perspective from China. Managing Service Quality. 14. (2/33), 2004, p. 169-182.

Wang, Younggui Hing-Po Lo and Yongheng Yang (2004). An Integrated Framework for Service Quality, Customer Value, Satisfaction: Evidence from China's Telecommunication Industry. Information system Frontiers 6:4, 325-340

Widjana Mahardika Aditya. 2010. Determinan Faktor Penerima terhadap Internet banking pada Nasabah Bank di Surabaya.Tesis. Surabaya. Sekolah Tinggillmu Ekonomi Perbanas.

Zhang Yong, Gang Wan, Liuting Huang and Qiong Yao (2015). Study on the Impact of Perceived Network Externalities on Consumers' New Product Purchase Intention. Journal of Service Science and Management, 2015, 8, 99-106. 